\title{
Effect of anaerobic fungi on the ruminal proteolysis in gnotobiotic lambs
}

\author{
F Bonnemoy 1,2 , G Fonty ${ }^{1 *}, 2$, V Michel 1 , P Gouet 1 \\ 1 INRA, Laboratoire de Microbiologie, Theix, 63122 Saint-Genès-Champanelle; \\ 2 Laboratoire de Biologie Comparée des Protistes, CNRS, URA 138, Université Blaise \\ Pascal Clermont-Ferrand, 63170 Aubière, France
}

(Received 12 July 1993; accepted 31 August 1993)

\begin{abstract}
Summary - The establishment of a fungal population composed of the main species usually found in ruminants in the rumen of gnotobiotic lambs did not significantly alter the in sacco digestibility of meat meal and soybean cake. The proteolytic activity of the rumen fluid against ${ }^{14} \mathrm{C}$-casein was not affected by the fungi. Therefore, these microorganisms probably do not play an important role in the degradation of proteins in the rumen.
\end{abstract}

rumen / proteolysis / anaerobic fungi / chytridiomycetes

Résumé - Effet des champignons anaérobies sur la protéolyse ruminale chez des agneaux gnotobiotiques. L'implantation dans le rumen d'agneaux gnotobiotiques d'une population fongique composée des principales espèces habituellement rencontrées chez les ruminants n'a pas amélioré la digestibilité in sacco de la farine de viande et du tourteau de soja. De même l'activité protéolytique du jus de rumen à l'égard de la ${ }^{14} \mathrm{C}$-caséine n'a pas été significativement modifiée en présence des champignons. II est par conséquent peu vraisemblable que ces micro-organismes jouent un rôle important dans la protéolyse ruminale.

rumen / protéolyse / champignons anaérobies / chytridiomycètes

\section{INTRODUCTION}

It is now well established that anaerobic fungi are autochtonous members of the rumen ecosystem (Orpin and Joblin, 1988; Fonty and Joblin, 1991) and that they may play an important role in rumen fermentation (Fonty et al, 1990). There have been several recent in vitro studies of their cellulolytic and hemicellulolytic activities (Lowe et al, 1987; Williams and Orpin, 1987a,b; Hébraud and Fèvre, 1988; Bernalier et al, 1991, 1992). These functions have also been observed in vivo in gnotobiotic lambs (Fonty and Gouet, 1989; Fonty et al, 1992). In contrast, the proteolytic activity of the fungi is a matter of debate. Wallace and Joblin (1985) and Wallace and Munro (1986) reported that strain $\mathrm{PNK}_{2}$ of $\mathrm{NeO}$ callimastix frontalis had a relatively high

\footnotetext{
* Correspondence and reprints
} 
proteolytic activity, whereas, of the 7 strains studied by Michel et al (1993), only one, a Piromyces sp strain, exhibited hydrolytic activity against casein. Furthermore, the activity was very weak. All 7 strains, however, showed aminopeptidase activity.

The aim of this work was to study the effect of these chytridiomycetes on the ruminal proteolysis in gnotobiotic lambs reared in sterile isolators.

\section{MATERIAL AND METHODS}

\section{Animals}

Three naturally born lambs $(A, B, C)$ were left with their dams for $24 \mathrm{~h}$ and then placed in sterile isolators. They received sterile cow's milk (UHT) until the age of $70 \mathrm{~d}$. From 1 month of life they also had access to a sterile pelleted ration of dehydrated lucerne hay. The lambs were fitted with a permanent rumen cannula at 2.5 months of age (Fonty et al, 1988; Fonty and Gouet, 1989). Hence, they were isolated before the natural establishment of the fungi, which occurs around the age of $10 \mathrm{~d}$ (Fonty et al, 1987).

Table I. Composition of the fungal population inoculated in gnotobiotic lambs.

\section{Strain Genus or species Origin}

$\begin{array}{lll}\begin{array}{l}\text { MCH3 } \\ 8628\end{array} & \text { Neocallimastix frontalis } & \text { Sheep rumen } \\ & \text { Sheep rumen }\end{array}$

During the fifth week of life they received 3 separate administrations of a fungi-free bacterial inoculum of $1 \mathrm{ml}$ of a $10^{-6}$ dilution of rumen contents taken from a conventionally reared sheep (period I). At the age of 4 months (period II) the lambs were administered a fungal inoculum composed of 7 strains of anaerobic fungi (table I) isolated from the rumen and faeces of sheep and cows. The activity of these strains has been previously studied in vitro (Michel et al, 1993). The establishment of the fungi and the development of their population were regularly monitored throughout the experimental period by zoospore counts in the rumen content according to the roll-tube method described by Joblin (1981).

\section{Biochemical analysis}

During these 2 periods, we measured the DM disappearance of 2 protein-rich substrates (meat meal and soybean cake) in the 3 animals by the nylon bag method (Michalet-Doreau, 1990). Nylon bags containing meat meal $(2.5 \mathrm{~g}$ dry matter/bag) were removed from the rumen after 2, 4 and $7 \mathrm{~h}$ of incubation and those with soybean cake ( $2 \mathrm{~g}$ dry matter/bag) after 24 and $48 \mathrm{~h}$. Six bags were placed in the rumen of each lamb for each incubation time. The proteolytic activity against ${ }^{14} \mathrm{C}$-casein $\left({ }^{14} \mathrm{C}\right.$-methylated casein, Sigma) in the rumen contents of lambs $A$ and $B$ was determined in vitro, during the 2 periods according to the method described by Wallace and Joblin (1985). Three samples from each lamb were used for these measurements. The rumen contents were withdrawn through the cannula and filtered on a double layer of cheesecloth.

\section{Statistical analysis}

The effect of fungi on DM disappearance was tested for each substrate by an analysis of variance using the SAS GLM procedure (SAS Institute, 1985).

\section{RESULTS AND DISCUSSION}

The fungi became established in the rumen of the 3 lambs soon after inoculation. 
The fungal population, which reached a level of $10^{3}$ zoospores per $\mathrm{ml}$ of rumen content $8 \mathrm{~d}$ after the last inoculation, ranged between $10^{3}$ and $10^{4}$ zoospores $\mathrm{ml}^{-1}$ throughout the experimental period. The relative proportions of the different strains were not determined but all the morphological types present in the inoculum were found in the roll-tubes (monoand polycentric, rhizoidal and non-rhizoidal strains).

The results of the degradation of the meat meal and soybean cake in the nylon bags (table II) show that the establishment of anaerobic fungi in the rumen did not significantly alter the extent of DM disappearance or the rate of degradation. The fungi did not therefore enhance the degradation of the 2 protein-rich substrates.

The activity of the rumen fluid from lambs $A$ and $B$ varied widely between samples (table III), making it difficult to interpret the results. Neither of the animals showed variations in proteolytic activity in relation to the time of sampling. In the absence of fungi, although it was inoculated with the same bacterial flora and reared in the same conditions as lamb $A$, lamb $B$ had slightly greater activity against ${ }^{14} \mathrm{C}$-casein. This difference did not result in a more efficient digestibility in sacco of the meat meal and soybean cake. There was a slight average increase in activity in lamb A after establishment of the fungi but it was not significant. In animal B, however, the activity was slightly weaker in the presence of fungi, particularly before feeding, but again the variations were not significant. Although the fungal populations, as assessed by zoospore counts, reached comparable levels in the 2 animals, the relative proportions of the different strains may have been different. A higher population level of Piromyces LM 1 in lamb A, for example, could have been responsible for the slight increase in the proteolytic activity of the rumen fluid against ${ }^{14} \mathrm{C}$-casein during period $\mathrm{Il}$, since this strain was the only 1 of the 7 making up the inoculum in which proteolytic activity was evidenced in vitro (Michel et al, 1993).

This study is the first published work on the role of anaerobic fungi in the in vivo degradation of proteins. The results support those obtained in vitro by Michel et al (1993), who showed that these micro-

Table II. Percentage of DM disappearance a of meat meal and soybean cake in nylon bags after incubation in the rumen of gnotobiotic lambs in the absence or presence of anaerobic fungi.

\begin{tabular}{lllll}
\hline \multirow{2}{*}{$\begin{array}{l}\text { Substrate } \\
\text { Period of incubation }(h)\end{array}$} & \multicolumn{3}{c}{ Percentage of DM disappearance } \\
\cline { 3 - 5 } & & Absence of fungi & Presence of fungi & SEM \\
\hline \multirow{2}{*}{ Soybean cake } & 2 & 49.3 & 49.9 & 5.4 \\
& 4 & 51.7 & 55.5 & 4.1 \\
& 7 & 59.2 & 59.5 & 5.2 \\
Meat meal & 24 & 44.6 & 42.0 & 3.1 \\
& 48 & 44.8 & 44.0 & 2.3 \\
\hline
\end{tabular}

a The animal effect was not significant $(P \geq 0.05)$ and in consequence the nylon bags introduced in the 3 animals were pooled for the determination of the DM disappearance. 
Table III. Amount of ${ }^{14} \mathrm{C}$-casein $(\mu \mathrm{g} \pm \mathrm{SD})(n=3)$ degraded by $1 \mathrm{ml}$ rumen fluid in $1 \mathrm{~h}$ in the presence or absence of anaerobic fungi.

\begin{tabular}{llclll}
\hline & \multicolumn{2}{c}{ Absence of fungi } & & \multicolumn{2}{c}{ Presence of fungi } \\
\cline { 2 - 3 } \cline { 5 - 5 } & $T_{0}{ }^{a}$ & $T_{2}{ }^{b}$ & & $T_{0}{ }^{a}$ & $T_{2}{ }^{b}$ \\
\hline Lamb A & $168 \pm 22$ & $161 \pm 25$ & & $200 \pm 18$ & $182 \pm 39$ \\
Lamb B & $260 \pm 62$ & $232 \pm 73$ & & $165 \pm 52$ & $172 \pm 42$ \\
\hline
\end{tabular}

${ }^{a} T_{0}$ : rumen sample collected before feeding; ${ }^{b} T_{2}$ : rumen sample collected $2 \mathrm{~h}$ after feeding.

organisms have no great proteolytic activity. However, they contrast the finding of Wallace and Joblin (1985) and Wallace and Munro (1986), who reported a relatively high activity in vitro in strain PNK2 of $N$ frontalis.

In conclusion, this study indicates that anaerobic fungi probably do not play an important role in the degradation of dietary proteins in the rumen ecosystem.

\section{ACKNOWLEDGMENTS}

The authors thank B Michalet-Doreau (SRNH, INRA, Theix) for her valuable advice and G Andant for his skilled technical assistance.

\section{REFERENCES}

Bernalier A, Fonty G, Gouet P (1991) Cellulose degradation by two rumen anaerobic fungi in monoculture or in coculture with rumen bacteria. Anim Feed Sci Tech 32, 131-136

Bernalier A, Fonty G, Bonnemoy F, Gouet P (1992) Degradation and fermentation of cellulose by the rumen anaerobic fungi in axenic cultures or in association with cellulolytic bacteria. Curr Microbiol 25, 143-148

Fonty G, Gouet P (1989) Establishment of microbial populations in the rumen. Utilization of an animal model to study the role of the different cellulolytic microorganisms in vivo. In: The Roles of Protozoa and Fungi in Ruminant Digestion (JV Nolan, RA Leng, DI Demeyer, eds) Penambul Books, Armidale, pp 39-49

Fonty G, Joblin KN (1991) Rumen anaerobic fungi: their role and interactions with other rumen microorganisms in relation to fiber digestion. In: Physiological Aspects of Digestion and Metabolism in Ruminants (T Tsuda, Y Sasaki, R Kawashima, eds) Academic Press San Diego, CA, 655-680

Fonty G, Gouet P, Jouany JP, Senaud J (1987) Establishment of the microflora and anaerobic fungi in the rumen of lambs. J Gen Microbiol 123, 1835-1843

Fonty $G$, Roussel $O$, Gouet $P$, Chavarot $M$ (1988) Activité cellulolytique in vivo de Bacteroides succinogenes, Ruminococcus flavefaciens et Ruminococcus albus dans le rumen d'agneaux placés en isolateurs 24 heures après la naissance. Reprod Nutr Dev 28, 135-136

Fonty G, Joblin KN, Brownlee A (1990) Contribution of anaerobic fungi to rumen functions. In: The Rumen Ecosystem: The Microbial Metabolism and its Regulation (S Hoshino, R Onodera, H Minato, $\mathrm{H}$ Itabashi, eds) Jpn Sci Soc Press and Springer Verlag, Tokyo, pp 93-100

Fonty G, Williams AG, Bonnemoy F, Morvan B, Doré J, Gouet P (1992) Interactions between cellulolytic bacteria, anaerobic fungi and 
methanogens in the rumen of gnotobiotic lambs. Proc Int Conf Manipulation of Rumen Microorganisms to improve Efficiency of Fermentation and Ruminant Production. Alexandria, Egypt, 20-23 Sept 1992

Hébraud M, Fèvre M (1988) Characterisation of glycosides and polysaccharide hydrolases secreted by the rumen anaerobic fungi $\mathrm{NeO}$ callismatix frontalis, Sphaeromonas communis and Piromonas communis. J Gen Microbiol 134, 1123-1129

Joblin KN (1981) Isolation, enumeration and maintenance of rumen anaerobic fungi in roll tubes. Appl Environ Microbiol 42, 1119-1122

Lowe SE, Theodorou MK, Trinci APJ (1987) Cellulases and xylanase of an anaerobic rumen fungus grown on wheat straw lignocellulose, wheat straw holocellulose, cellulose and $\mathrm{xy}$ Ian. Appl Environ Microbiol 53, 1216-1223

Michalet-Doreau B (1990) Use of in sacco method to predict the feeding value of forages. Proc 16th Int Grassland Congress, 4-11 October, Nice, France, INRA, route de SaintCyr, vol 3, pp 1850-1852

Michel V, Fonty G, Millet L, Bonnemoy F, Gouet $P$ (1993) In vitro study of the proteolytic activ- ity of rumen anaerobic fungi. FEMS Microbiol Lett 110, 5-10

Orpin CG, Joblin KN (1988) The rumen anaerobic fungi. In: The Rumen Microbial Ecosystem (PN Hobson, ed) Elsevier Appl Sci, Lond, pp 129-150

SAS Institute (1985) User's Guide: Statistics, version 5 edition. SAS Int Inc, Cary NC

Wallace RJ, Joblin KN (1985) Proteolytic activity of a rumen anaerobic fungus. FEMS Microbiol Lett 29, 19-25

Wallace RJ, Munro CA (1986) Influence of the rumen anaerobi fungus Neocallimastix frontalis on the proteolytic activity of a defined mixture of rumen bacteria growing on a solid substrate. Lett App/ Microbio/ 3, 23-26

Williams AG, Orpin CG (1987a) Polysaccharide degrading enzymes formed by three species of anaerobic fungi on a range of carbohydrate substrates. Can J Microbio/ 33, 418-426

Williams AG, Orpin CG (1987b) Glycoside hydrolase enzymes present in the zoospore and vegative growth stages of the rumen fungi NeOcallimastix patriciarum, Piromonas communis and unidentified isolate, grown on a range of carbohydrates. Can J Microbio/ 33, 427-434 